\title{
Hakekat Dan Urgensi Pendidikan Islam Dalam Pengembangan Fitrah Manusia
}

\author{
Samsul Hakim,
}

Prodi PAI, STAI Al-Amin Gersik, Lombok Barat, Indonesia; aizoehakim@gmail.com

\begin{abstract}
Abstrak: Manusia diberi kelengkapan kemampuan jasmani dan rohani yang dapat ditumbuh-kembangkan seoptimal mungkin untuk melaksanakan tugas pokok kehidupan di muka bumi, yaitu untuk menjadi hamba Allah yang bertakwa dan mampu menebarkan rahmat bagi seluruh alam. Perkembangan kemampuan jasmani dan rohani manusia akan semakin terarah dalam perkembangannya ketika memperoleh bimbingan melalui proses pendidikan. Adapun fokus kajian dalam tulisan ini adalah bagaimana hakekat dan urgensi Pendidikan Islam dalam pengembangan fitrah manusia?. Metode penelitian dalam pembahasan ini menggunakan pendekatan kualitatif-deskriptif dengan jenis penelitian kepustakaan. Dari pembahasan kajian ini diperoleh kesimpulan bahwa hakikat pendidikan adalah mendidik manusia menjadi lebih baik. pengembangan fitrah manusia melalui pendidikan adalah sebuah keniscayaan dalam rangka membimbing manusia untuk mengaktualisasikan potensi-potensi yang dimilikinya baik potensi penghambaan maupun potensi kekhalifahannya.
\end{abstract}

Kata kunci: hakikat, urgensi, pendidikan, islam, fitrah, manusia.

Abstract: Humans are given complete physical and spiritual abilities that can be grown and developed as optimally as possible to carry out the main tasks of life on earth, namely to become servants of God who are pious and able to spread mercy to the whole world. The development of human physical and spiritual abilities will be more focused on their development when they receive guidance through the educational process. The focus of the study in this paper is the concept and urgency of Islamic education in the development of human character? The research method in this discussion uses a qualitative-descriptive approach to the type of library research. From the discussion of this study, it can be concluded that the essence of education is to educate people to be better. The development of human nature through education is necessary to guide humans to actualize their potentials, both the potential for servitude and the caliphate.

Keywords: Consept, urgency, education, Islam, character, human.

\section{PENDAHULUAN}

Allah SWT. menciptakan manusia dimuka bumi ini tidaklah untuk di sia-siakan begitu saja, dalam arti manusia diciptakan dengan tujuan yang pasti oleh penciptaanya. Dia memberikan petunjuk kepada manusia berupa kita suci melalui para nabi dan utusan-Nya kepada manusia, supaya menjadi petunjuk dan pedoman bagi jalan hidupnya. Sebagaimana firman Allah yang berbunyi:

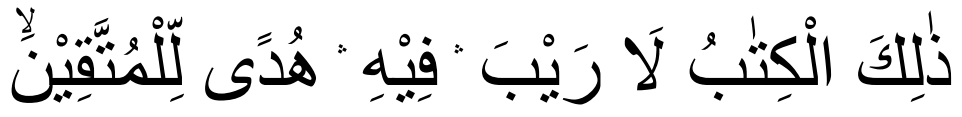


Kitab (Al-Qur'an) ini tidak ada keraguan padanya; petunjuk bagi mereka yang bertakwa (QS. Al-Baqarah: 2)

Demikian juga Allah menganugerahkan kepada manusia akal pikiran sebagai potensi dasarnya alat untuk memperoleh petunjuk dari-Nya dan mengajarkannya ilmu pengetahuan, melalui proses pengajaran sebagaimana pengajaran terhadap dam as. sebagaimana firman Allah yang berbunyi:

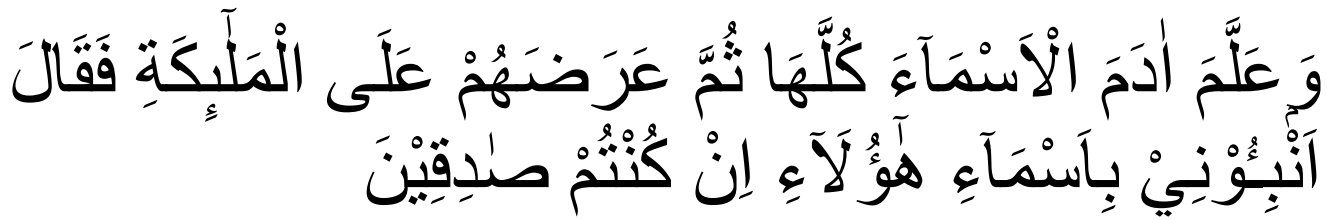

Dan Dia ajarkan kepada Adam nama-nama (benda) semuanya, kemudian Dia perlihatkan kepada para malaikat, seraya berfirman, "Sebutkan kepada-Ku nama semua (benda) ini, jika kamu yang benar! (QS. Al-Baqarah: 31)

Sebagai hamba dan khalifah, manusia diberi kelengkapan kemampuan jasmani dan rohani yang dapat ditumbuhkembangkan seoptimal mungkin sehingga menjadi alat yang berdaya guna dalam ikhtiar kemanusiaannya untuk melaksanakan tugas pokok kehidupan di muka bumi, yaitu untuk menjadi hamba Allah yang bertakwa dan mampu menebarkan rahmat bagi seluruh alam. Kemampuan jasmani dan rohani yang diberikan Allah merupakan sarana untuk mendapatkan ilmu pengetahuan yang merupakan syarat untuk melakukan amal shaleh dan membangun dunia. Karena itu, dengan potensi yang dimilikinya manusia dapat menjadi makhluk yang aktif, kreaktif, kaya akan kebijaksanaan, berpengetahuan luas, berpikir bebas, berpandangan lapang dada dan terbuka serta bersedia mengikuti kebenaran dari manapun datangnya. ${ }^{1}$ Perkembangan kemampuan jasmani dan rohani manusia akan semakin terarah dalam pembentukan dan perkembangannya ketika memperoleh bimbingan melalui proses pendidikan.

Pendidikan dapat diartikan sebagai proses bimbingan secara sadar oleh pendidik terhadap perkembngan jasmani dan rohani manusia menuju terbentuknya kepribadian yang utama. Oleh karena itu, pendidikan dipandang sebagai salah satu aspek yang memiliki peranan pokok dalam membentuk generasi muda agar memiliki

${ }^{1}$ Muhammad Ereska, Pensucian Jiwa. Terj.(Jakarta: Iqra Kurnia Gemilang, 2005), h. 20 
kepribadian yang utama. ${ }^{2}$ Pendidikan menduduki posisi penting dalam kehidupan manusia, sehingga menjadi suatu yang wajjar ketika pendidikan Islam membicarakan tentang pendidikan, kiranya tidak akan lepas dari pembahasan mengenai upaya memberdayakan seluruh potensi (fitrah) manusia.

Tumpuan dari pendidikan Islam adalah fitrah manusia, hal ini didasarkan pada konsep pendidikan Islam yang banyak dikemukakan oleh para pakar pendidikan Islam yang mengemukakan bahwa pendidikan Islam merupakan suatu kegiatan yang mengarahkan dengan sengaja perkembangan manusia sesuai atau sejalan dengan nilai-nilai Islam. Sehingga konsep pendidikan Islam dapat digambarkan sebagai suatu sistem yang membawa manusia kearah kebahagian dunia dan akhirat melalui ilmu dan ibadah. Karena pendidikan Islam membawa manusia untuk kebahagian dunia dan akhirat, maka yang harus diperhatikan adalah "nilai-nilai" Islam tentang manusia, hakikat dan sifat-sifatnya, misi dan tujuan hidupnya di dunia ini dan akhirat nanti, hak dan kewajibannya sebagai individu dan anggota masyarakat, semua ini dapat kita jumpai dalam Al-Qur'an dan Al-Hadits.

Berdasarkan gambaran tersebut maka fokus kajian dalam tulisan ini adalah bagaimana hakekat dan urgensi Pendidikan Islam dalam pengembangan fitrah manusia? Sehingga dalam pembahasan dan kajian selanjutnya memiliki tujuan untuk mengetahui memberikan pemahaman tentang hakekat dan urgensi pendidikan Islam pada posisinya dalam mengembangakan fitrah manusia.

\section{METODE PENELITIAN}

Karena data-data dari pembahasan dalam kajian fokus penelitian ini dilakukan melalui pengamatan dari buku-buku dan literatur-literatur yang ada di perpustakaan maka metode penelitian dalam pembahasan focus kajian ini menggunakan pendekatan kualitatif-deskriptif dengan jenis penelitian kepustakaan (library research). Penelitian kualitatif merupakan proses penelitian yang menghasilkan data deskriptif yang berupa kata-kata tertulis atau lisan dari orang dan perilaku yang dapat diamati. ${ }^{3}$

${ }^{2}$ Zuhairini, Abdul Ghofir, Metodologi Pembelajaran Pendidikan Agama Islam (Malang: UIN dan UM Press, 2004), hlm. 1

${ }^{3}$ Lexy J.Moleong, Metodlogi Penelitian Kualitatif (Bandung: Remaja Rosda Karya, 2013), h.4. 
Perolehan atau pengumpulan data-data dalam kajian ini dilakukan dengan metode dokumentasi yakni dengan mengumpulkan berbagai informasi terkait hakekat dan urgensi Pendidikan Islam dalam pengembangan fitrah manusia melalui buku, kitab, ataupun literatur-literatur lainnya yang memiliki data-data yang relevan dengan pembahasan tersebut. Metode dokumentasi, yaitu suatu metode yang digunakan untuk mencari data menganai hal atau variabel yang berupa catatan atau transkip, majalah, surat kabar, prasasti, notulen, agenda dan sebagainya. ${ }^{4}$

Data-data yang diperoleh selanjutnya dianalisis dengan menggunakan dengan menggunakan analisis flow model (analisis megalir) yang terdiri dari tiga komponen yang dilakukan bersamaan yaitu reduksi data, display data dan mengambil kesimpulan/verifikasi. Analisis data adalah salah satu tahapan yang dikerjakan setelah memperoleh informasi melalui beberapa teknik pengumpulan data, dan bertujuan untuk menyempitkan dan membatasi temuan-temuan sehingga menjadi suatu data yang teratur dan akurat. Menurut Sugiyono Teknik analisis data dalam penelitian kualitatif lebih banyak dilakukan bersamaan dengan pengumpulan data. ${ }^{5}$

\section{HASIL DAN PEMBAHASAN}

\section{A. Hakekat Pendidikan Islam}

\section{Pengertian Umum Pendidikan}

Istilah pendidikanberasal dari kata "didik" dan dan selanjutnya karena tambahan tambahan awalan dan akhiran "pe-an" berubah menjadai "mendidik” yang dartikan sebagai sebuah proses bimbingan untuk peserta didik dalam menguasai berbagai pengetahuan, keterampilan, sikap, dan nilainilai yang di dapatkan dari keluarga dan lingkungan masyarakatnya. Istilah "pedagogiek" yang beasal dari Bahasa Yunani merupakan padanan istilah pendidikan yang memiliki arti ilmu yang mengarahkan anak. Selanjutnya istilah lainyang juga berasal dari Bahasa Yunani yakni "pedagogia" yang diartikan pergaulan dengan anak-anak. Padanan lain dari istilah pendidikan

${ }^{4}$ Suharsimi Arikunto, Prosedur Penelitian Suatu Praktek (Jakarta: Reneka Cipta, 2006), h.158.

${ }^{5}$ Sugiyono, Metode Penelitian Pendidikan; Pendekatan Kuantitatif, Kualitatif, dan RED, (Bandung: Alvabeta, 2014.) h. 401. 
adalah "educare". Istilah ini berasal dari Romawi yang bermakna mengeluarkan dan menuntun, serta tindakan yang mewujudkan potensi anak yang dibawanya sejak lahir. 6

Konsep pendidikan lebih lanjut banyak di kemukakan para tokoh baik dari kalangan barat maupun tokoh-tokoh pendidikan nasional yang memberikan difinisi-definisi menurut pandangan dan pemahaman mereka masing-masing seperti hanya John Dewey yang memberikan definisi pendidikan sebagai sebuah proses pembentukan kecakapan-kecakapan fundamental baik dalam ranah intlektual maupun dalam ranah emosional kearah alam dan sesama manusia. Sementara itu Jean Jaques Rousseau mengemukakan konsep pendidikansebagai usaha dalam memberi bekal yang belum ada pada masa kanak-kanak namun dibutuhkan pada masa dewasanya. 7 dan menurut pendapat Ali Asraf dengan mengutip Teguh Wangsa Gandhi mengemukakan bahwa pendidikan adalah upaya melatih perasaan muridmurid sehingga dalam sikap, tindakan, keputusan atau pendekatan mereka terhadap segala jenis pengetahuan dipengaruhi sekali oleh nilai spiritual dan sangat sadar akan nilai etika. ${ }^{8}$

Dari sekian banyak pendapat dan konsep pendidikan yang dikemukakan oleh pada tokoh-tokoh pendidikan tersebut intinya adalah bahwa pendidikan merupakan Usaha sadar yang dilakukan seseorang dalam memberikan bimbingan, asuhan, didikan pada anak didik agar dia berkembang sehingga mampu menyempurnakan kepribadian secara maksimal sehingga mampu menyesuaikan diri dengan sesamanya, Alam semesta dan juga dengan sang penciptanya. yang selanjutnya akan menjadikan dia sebagai individu-individu yang lebih baik.

\section{Konsep Dasar Pendidikan Islam}

${ }^{6}$ Arif Rohman, Memahami Pendidikan dan Ilmu Pendidikan, (Cet.II;Yogyakarta:Aswaja Pressindo, 2011), h. 5 .

${ }^{7}$ Ibid, h. 6-7

${ }^{8}$ Teguh Wangsa Gandhi HW., Filsafat Pendidikan; Madzhab-madzhab Filsafat Pendidikan, (Yogyakarta:ar-russ Media, 2011), h. 63 
Padanan istilah pendidikan Islam yang sering dipakai dalam Dunia Islam adalah at-tarbiyah, at-ta'dib dan at-ta'lim. Istilah yang berkembang secara umum didunia Arab adalah tarbiyah. Salah satu bentuk penggunaannya terlihat pada penamaan fakultas-fakultas pendidikan dengan kulliyah attarbiyah, yang di Indonesia disebut Fakultas Tarbiyah. Istilah ini, menurut Muhammad Munir Musa, muncul berkaitan dengan gerakan pembeharuan pendidikan di dunia Arab pada perempat kedua abad ke-20. Oleh sebab itu, penggunaannya dalam konteks pendidikan menurut pengertian sekarang tidak ditemukan didalam referensi-referensi lama. Yang ditemukan adalah istilah-istilah seperti $t a^{\prime} l i m$, adab dan tahdzib. ${ }^{9}$

Istilah tarbiyah yang digunakan untuk pendidikan dalam Islam sesungguhnya tidak terdapat dalam al-Qur'an seperti apa yang dikemukakan Abdul mujib yang dikutip Ramayulis menyatakan bahwa dalam alquran tidak ditemukan kata al tarbiyat namun terdapat istilah lain yang memiliki makna yang seakar dengannya yakni al-rabb, rabbayani, murabbiy, yurbiy dan rabbaniy,.${ }^{10}$ Ayat yang bermakna pendidikan terdapat dalam surat al Isra ayat $24:$

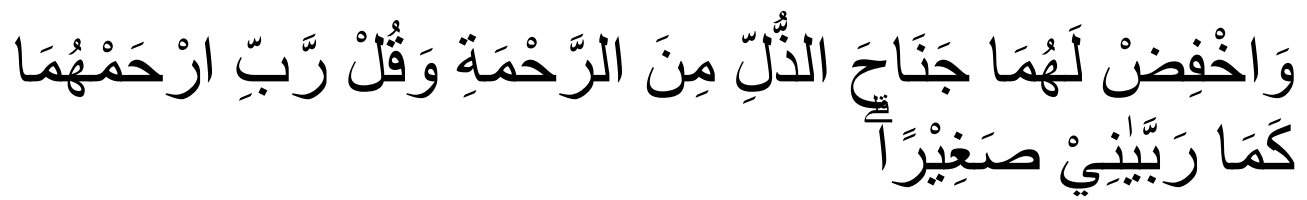

Dan Rendahkan dirimu terhadap mereka berdua dengan penuh kesayangan dan ucapkanlah: "Wahai Rabbku, Kasihinilah mereka keduanya, sebagaimana mereka berdua telah mendidik aku sewaktu kecil ( QS.al Mujadalat:24)

Menurut Abul A'la al Maududi yang juga dikuti Ramayulis bahwa kata tarbiyah berasal dari kata Rabbi yang selain memiliki arti pendidikan, pengasuhan juga memiliki arti selain itu seperti kekuasaan, perlengkapan, pertanggung jawaban, perbaikan, penyempurnaan dan lainnya, kata ini juga merupakan predikat bagi suatu kebesaran, keagungan, kekuasaan, dan kepemimpinan. Menurut Zakiah Drajat Pendidikan Islam adalah usaha untuk membina dan mangasuh peserta didik agar senantiasa memahami ajaran Islam

${ }^{9}$ Hery Noer Aly, Ilmu Pendidikan Islam, (Jakarta: Logos, 1999),h. 3-4 
secara menyeluruh, dan mnghayati tujuan yang pada akhirnya dapat mengamalkan serta menjadikan Islam sebagai pandangan hidup

Secara sederhana Pendidikan Islam dapat dipahami dalam beberapa pengertian yakni :

1. Pendidikan Menurut Islam atau pendidikan islam yaitu pendidikan yang dipahami dan dikembangkan dari ajaran dan nilai-nilai fundamental berdasarkan al-Quran dan sunnah

2. Pendidikan Ke-Islam-an atau pendidikan agama islam yaitu upaya pendidikan agama Islam atau ajaran Islam dan Nilai-nilainya, agar menjadi way of life (Pandangan dan sikap hidup) seseorang.

3. Pendidikan dalam atau proses dan praktek penyelenggaraan pendidikan yang berlangsung dan berkembang dalam sejarah umat. 11

Jadi dapat kita simpulkan Pendidikan islam adalah Usaha sadar yang dilakukan seseorang dalam memberikan bimbingan, asuhan, didikan pada anak didik agar dia berkembang sehingga mampu menyempurnakan kepribadian secara maksimal sesuai dengan konsep Islam (al-Qur'an dan alHadits) sehingga mampu menyesuaikan diri dengan sesamanya, Alam semesta dan juga dengan sang penciptanya. yang selanjutnya akan menjadikan dia sebagai individu-individu yang lebih baik

Dengan demikian secara umum hakikat pendidikan adalah mendidik manusia menjadi lebih baik. demikian pula dengan hakikat pendidikan Islam yangh mencakup definisi ketika manusia dibimbinguntuk menjadi pribadi beriman yang kuat secara fisik, mental dan spiritual serta cerdas, berakhlak mulia dan memiliki keterampilan yang diperlukan bagi kebermamfaatan dirinya , masyarakatnya, dan lingkungannya, dalam kerangka meraih kesuksesan hidup didunia dan akhirat.

\section{Prinsip-Prinsip Pendidikan Islam}

Karena manusia telah diciptakan dengan fitrah dengan segala potensi yang dikaruniainya maka untuk mencapai tujuan serta mengaktualisasikan

11 Muhaimin, dkk. Paradigma Pendidikan Islam; Upaya mengefektifkan pendidikan agama Islam disekolah, ( Bandung;PT Remaja Rosda Karya, 2002) ,h. 29-30 
potensi-potensi tersebut maka dibutuhkan pendidikan yang tentunya berdasrkan prinsip-prinsip yang banyak tersurat dan tersirat dalam alqur an dan al- hadits . diantara prinsip-prinsip yang dikemukakan Abudin Nata adalah ${ }^{12}$ :

a. Prinsip integrasi(tauhid),

prinsip ini memandang adanya wujud kesatauan dunia dan akhirat, oleh karena itu pendidikan akan meletakkan porsi yang seimbang untuk mencapai keseimbangan dunia dan akhirat

b. Prinsip keseimbangan

adalah merupakan konsekuensi dari prinsip integrasi. Keseimbangan yang proporsional antara muatan rohaniah dan jasmaniah, antara ilmu murni dan ilmu terapan, teori dan praktek dan nilai-nilai yang menyangkut tentang akidah syariah dan akhlak.

c. Prinsip kesetaraaan,

prinsip ini menekankan agar di dalam pendidikan islam tidak terdapat ketidakadilan perlakuan,atau diskriminasi.Tanpa membedakan suku,ras,jenis kelamin,status social,latar belakang dsb, karena semua makhluk hidup diciptakan oleh tuhan yang sama,Allah SWT.

d. Prinsip Pembaharuan

Prinsip pembaharuan merupakan perubahan baru dan kualitatif yang berbeda dari hal sebelumnya. Serta diupayakan untukmeningkatkan kemampuan guna mencapai tujuan tertentu pendidikan.Menurut H.M Arifin,dalam proses pembaharuan umat islam harus mampu menciptakan model-model pendidikan yang dapat menyentuh beberapa aspek yaitu: yang mampu mengembangkan agent of technology and culture.

e. Prinsip Demokrasi

Berasal dari kata demos: rakyat,cratein : pemerintah,prinsip pendidikan ini mengidealkan adanya partisipasi dan inisiatif yang penuh dari masyarakat.Segala sesuatu yang dibutuhkan dalam pendidikan seperti

12 Abudin Nata,Ilmu Pendidikan Islam (Jakarta: Kencana Prenada Media Grup,2010),h. 102 
sarana dan prasarana, infrastruktur, administrasi, penggunaan sarjana dan sumber daya manusia lainnya hanya akan dapat diperoleh dari masyarakat. Prinsip pendidikan yang berbasis masyarakat ini sejalan dengan dengan Undang-undang Sistem Pendidikan Nasional,yang menyatakan bahwa pendidikan merupakan tanggung jawab pemerintah,orang tua dan masyarakat.

f. Prinsip Kesinambungan

Prinsip yang saling menghubungkan antara berbagai tingkat dan program pendidikan.

g. Prinsip Pendidikan Seumur Hidup (Long Life Education),menjelaskan bahwasanya agar setiap orang dapat terus belajar dan meningkatkan dirinya sepanjang hidupnya.Tidak pernah lelah untuk menuntut ilmu,dengan alasan ilmu dan pengetahuan itu selalu mengalami perkembangan, pembaharuan dan pergantian

Pendidikan Islam berpadu dalam pendidikan ruhiyah, fikriyah dan amaliyah (aktivitas). Nilai Islam ditanamkan dalam individu membutuhkan tahpan-tahapan selanjutnya dikembangkan kepada pemberdayaan di segala sektor kehidupan manusia. Potensi yang dikembangkan kemudian diarahkan kepada pengaktualan potensi dengan memasuki berbagai bidang kehidupan.

Pendidikan yang diajarkan Allah SWT melalui Rasul-Nya bersumber kepada Al Qur'an sebagai rujukan dan pendekatan agar dengan tarbiyah akan membentuk masyarakat yang sadar dan menjadikan Allah sebagai Ilah saja.Kehidupan mereka akan selamat di dunia dan akhirat. Hasil ilmu yang diperolehnya adalah kenikmatan yang besar, yaitu berupa pengetahuan, harga diri, kekuatan dan persatuan.

\section{B. Urgensi Pendidikan dalam Pengembangan Fitrah Manusia}

\section{Manusia sebagai Subjek dan Objek Pendidikan}

Manusia sebagai Subjek dan objek pendidikan dapat diklasifikasikan sebagai makhluk biologis, psikologis dan sosial,, dimana ketiganya harus memiliki keseimbangan dalam pengembangannnya dan masing-masing harus selalu berada dalam hukum-hukum yang berlaku (sunatullah) 
Demikian juga komposisi manusia yang terdiri dari dua unsur besar (jasmani dan rohani) merupakan referensi utama dalam aktivitasmanusia sebagai subjek dan objek pendidikan. Pendidikan dalam dimensi ini merupakan sarana dan instrumenuntuk mengembangkan potensi jasmaniah dan ruhaniah mausia secara seimbang,. karenanya orientasi pendidikan dimaksudkan untuk mewujudkan jasmani sehat dan ruhaniu sehat . indikator terpainya orientasi ini terletak pada berfungsinya organ-organ fisik jasmaniah dan psikis ruhaniah secara maksimal. ${ }^{13}$

Didalam al-Qur'an ada tiga istilah kunci untuk mengacu pada makna pokok manusia, yakni pertama,. Al-basyr menunjukkan manusia sebagai makluk biologis, manusia tipe ini memiliki esensi kemanusiaan yang tidak tampak dan aktivitasnya serupa dengan binatang, sehingga ia tidak dapat dikatakan sebagai hamba dan khalifah Allah . Kedua, Konsep al-insan merupaka perwujudan manusia sebagai makhluk psikologis yakni manusia yang dapat menunjukkan esensi kemanusiaannya secara pribadi sebagai khalifah karena manusia tipe ini memiliki ilmu pengetahuan dan memiliki nalar sebagi makhluk rsionil. yang dengan pengetahuan dan akalnya dia mampu menjadi khalifah Allah. dan yang Ketiga, konsep al-nas merupakan konsep yang mengacu kepada manusia sebagai makhluk sosial, ${ }^{14}$

Achmadi mengemukakan bahwa manusia tidak dapat dipandang sebagai makhluk reaktif, melainkan responsible (bertanggung jawab). Oleh karena itu pendidikan sebenarnya adalah pendidikan yang memberikan stimulus dan dilaksanakan secara demokratis . bukan memberikan ilmu atau nilai-nilai, seakan guru sebagai sumber ilmu dan gudang nilai, dan peserta didik ibarat botol kosong yang siap diisi . pendekatan demokratis ini sesuai dengan fitrah manusia yang meberikan kebebasan saat murid mengemban tanggung jawab dalam interaksi pendidikan ${ }^{15}$

${ }^{13}$ Ismail Thaib, Wacana Baru Pendidikan, ( Cet.II;Yogyakarta:Genta Press,2008), h. 11

14 Ibid, h. 9-10

15 Achmadi, Ideologi Pendidikan Islam;Paradigma Humanisme Teosentris, (Yogyakarta:Pustaka Pelajar,2005), h. 74. 
Setiap individu manusia memiliki fitrah dan potensi-potensi positif, namun jika seorang individu tidak mampu meaktualkan atau meraih potensipotensi tersebut maka akan menyebabkan sebuah kelemahan yang akan menyebabkan ganggiuan dan hambatan internal dalam pribadinya. Karena terdapatnya kelemahan dan kekurangan inilah maka tugas seorang pendidik sangat diperlukan untuk menetralisai faktor-faktor penghambat tersebut.

Menurut Samsul Nizar, Jika ditinjau dari konsep manusia sebagai makhluk yang memiliki fitrah dan potensi, maka terdapat dua implikasi apabila dikorelasikan dengan pendidikan, yaitu :16

a. karena manusia adalah makhluk yang merupakan resultan dari dua komponen (materi dan Immateri), maka konsepsi menghendaki proses pembinaan yang mengacu kearah realisai dan pengembangan komponenkomponen tersebut. hal ini berarti bahwa system pendidikan Islam harus dibangun atas konsep kesatuan (integrasi) antara pendidikan Qalbiyah dan Aqliyah sehingga mampu menghasilkan manusia muslim yang pintar secara intlektual dan terpuji secara moral. Apabila kedua komponen tersebut dipisahkan dalam proses pendidikan Islam, Maka manusia akan kehilangan keseimbangannya dan tidak akan pernah menjadi pribadipribadi yang sempurna (al-Insan Kamil)

b. Al-Quran menjelaskan bahwa fungsi penciptaan manusia adalah sebagai Khalifah dan "abd. Untukm melaksanakan fungsi manusia tersebut. Allah membekali manusia dengan seperangkat potensi . Dalam kontek ini Pendidikan Islam harus ditujukan kearah pengembangan potensi yang dimiliki manusia secara maksimal sehingga dapat diwujudkan dalam bentuk kongkrit. artinya dapat menciptakan sesuatu yang bermamfaat bagi diri, masyarakat dan lingkungannya sebagai realisai fungsi dan tujuan penciptaannya, baik sebagai khalifah maupun 'abd.

\section{Pengembangan Fitrah manusia melalui Pendidikan}

16 Samsul Nizar, Filsafat Pendidikan Islam;pendekatan Historis, Teoritis dan Praktis, (Jakarta: Ciputat Pers, 2002),h. 21-22 
Manusia diciptakan untuk berbakti kepada Tuhan dengan penuh iklas . funsi pendidikan adalah mengantar manusia menuju Tuhan. Oleh karena itu pendidikan sebagai sarana pengejawantahan alam menjadi sangat urgen untuk menggunakan proses dan prosedur pemamfaatan alam secara maksimal dalam menggunakan proses dan prosedur pemamfaatan ala mini manusia dibekali Tuhan dengan sifat-sifat ketuhanan, yakni sifat qudrat iradah Tuhan. Sehingga manusia mampu melakukan Olah potensi pemamfaatan alam. ${ }^{17}$

Namun dalam kenyataan tidak terpungkiri bahwa hanya sebagian manusia yang melaksanakan tugasnya kehambaannya. dan sebagian yang lain menodai perjanjian asasinya dengan sang pencipta. penomean ini terjadi karena sesungguhnya Tuhan memberikan potensi akal akal kepada manusia untuk melakukan pemilahan dan pemilihan tentang mana yang baik dan buruk, dan sebagai referensi putusan manusia Tuhan berikan al-qur'an yang berisi aturan main dengan segala konsekwensi logis dari decision yang dipilih dan diputus manusia. ${ }^{18}$

Pendidikan merupakan hubungan sinergis antara Tuhan, Manusia dan Alam. Konsep ini menunjukkan keterpaduan gerak yang membentuk peserta didik kea rah insan kamil, Insan kamil dimaknai sebagai manusia yang berperilaku berdasarkan perilaku risalah kenabian, beriman, bersyariat, dan berikhsan untuk mencapai kehidupan yang diridhai Allah pencipta semesta lam. ${ }^{19}$

Sebagai manusia yang mempunyai keyakinan akan kekuatan Tuhan, maka pendidikan yang ideal adalah kembali untuk Tuhan,sedangkan proses untuk sampai ketujuan akhir itu adalah memamfaatkan alam sebagai sarana dengan bijak, yang dalam Islam disebut Akhlaq karimah. disebut bijak adalah suatu proses seseorang yang mengenyam pendidikan mampu menciptakan

${ }_{17}$ Ahmad Ali Riadi, Filsafat Pendidikan Islam, (Cet.I;Yogyakarta:Teras,2010), h.187-188

${ }^{18}$ Ismail Thaib, Wacana Baru Pendidikan,( Cet.II;Yogyakarta:Genta Press,2008), 15

${ }^{19}$ Ahmad Ali Riadi, ..., h. 186 
kearifan lingkungan. Jadi Keseimbangan antara kepentingan manusia, Tuhan dan alam menunjuk keberhasilan pendidikan ${ }^{20}$

Pendidikanlah yang mampu memberikan manusia makna kehidupan, tinggi rendahnya kualitas pendidikan yang dimiliki seorang manusia akan berpengaruh signifikan dalam melaksanakan tugas kehambaan dan kekhalifahannya. Pendidikan yang dimaksud bukan hanya pendidikan dalam maknanya yang forma, akan tetapi pendidikan dalm arti yang seluasluasnya, pendidikan formal apapun bentuk dan tingkatannya bukanlah variable satu-satunya dalam mengukur kualitas kemanusiaan manusia.

Pendidikan memiliki fungsi yang sangat menentukan bagi manusia dalam melaksanakan tugas-tugas kehambaannnya, makna terpenting pendidikan bagi manusia dalam melaksanakan fungsi kehambaan ini adalah bahwa pendidikan harus mampu memberikan pengetahuan dan keterampilan yang dibutuhkan oleh manusia untuk melaksanakan fungsi kehambaan dan kekhlaifahannya yang sempurna

Perolehan pengetahuan dan keterampilan manusia ini tentu tidak terlepas dari bagaimana manusia mendapatkannya, ilmu dapat dicapai melalui dua metode; yakni metode pengajaran alam dan manusia ( ta' allum alinsan) dan pengajaran dari Tuhan (Ta'allum al-Rabbani)yang pertama merupakan metode yang biasa dilakukan di lembaga-lembaga bersifat formaldan non formal yang mengandalkan komunikasi secara interpersonal maupun interaksi social . sedangkan yang kedua merupakan metode pengajaran yang melibatkan komunikasi manusia dengan Tuhan . Dari model pembelajaran yang kedua inilah kemungkinan ilmu dapat diperoleh manusia dengan ta'arruf kepada Allah lewat penjernihan jiwa . Ilmu yang berasal dari manusia dan alam disebut ilmu khusuli yang didasarkan pada akal sedang ilmu yang berasal dari Tuhan adalah ilmu Khuduri (ilmu yang dihadirkan) yang disebut pula mukasyafah yang bersifat Kasf, Supra Rasional, Intuitif dan kontemplatif. ${ }^{21}$

${ }^{20}$ Ibid, h. 187

${ }^{21}$ Ibid, h. 185 
Dengan metode apaun manusia mendapatkan Ilmu dalam proses pendidikannnya namun hal paling substansial adalah indikator terdidik yang diberikan alquran bagi manusia yakni diukur dari kualitas iman dan Ilmunya karena sesungguhnya Islam Tuhan Mengangkat derajat orang-orang beriman dan berilmu pengetahuan berberapa derajat seperti yang tersurat dalam Q.S al-Mujadalah;

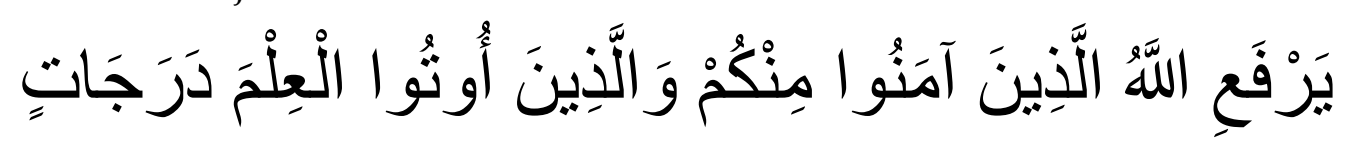

Allah akan meninggikan orang-orang yang beriman dan berilmu pengetahuan diantara kamu beberapa derajat". (Q.S. Al Mujadalat, 11)

Kualitas iman dan ilmu manusia diukur pada pencapaian amal sholehnya itu sendiri akan tampak pada kualitas kebermaknaan eksistensi manusia dalam hubungannya dengan alam semesta. Manusia terbaik dalam beramal sholeh adalah manusia yang paling bermamfaat bagi makhluk lain di alam semesta ini. ${ }^{22}$

Manusia menurut Jalaludin adalah makhluk ekploratif dan sekaligus juga makhluk alternative, makhluk yang berkembang dan mampu mengembangkan diri, bukan makhluk yang lahir langsung jadi dewasa. Juga bukan makhluk instunktif, yang ketika lahir sudah mampu mengembangkan dan memamfaatkan potensi dirinya secara siap pakai. Sebagai makhluk alternative, manusia berpotensi untuk berbuat kebaikan dan juga keburukan. ${ }^{23}$

Berangkat dari penjabaran ini maka pengembangan fitrah manusia melalui pendidikan adalah sebuah keniscayaan dalam rangka membimbing manusia untuk mengaktualisasikan potensi-potensi yang dimilikinya baik potensi penghambaan maupun potensi kekhalifahannya. Pendidikan menjadi kebutuhan mutlak manusia dalam kapasitasnya sebagai hamba karena sesungguhnya hungan manusia dan pendidikan itu sendiri adalah ibadah. dan

22 Ismail Thaib, Wacana ..., h.18. 2011), h.108.

${ }^{23}$ Jalaluddin, Filsafat Pendidikan Islam; Telaah Sejarah dan pemikirannya,(Jakarta:Kalam Mulia, 
dalam kapasitasnya sebagai khalifah pendidikan menjadi syarat utama dalam meraih potensi dan kelebihan-kelebihannya dibanding makhluk lainnya.

\section{KESIMPULAN}

A. Hakikat pendidikan adalah mendidik manusia menjadi lebih baik. demikian pula dengan hakikat pendidikan Islam yangh mencakup definisi ketika manusia dibimbinguntuk menjadi pribadi beriman yang kuat secara fisik, mental dan spiritual serta cerdas, berakhlak mulia dan memiliki keterampilan yang diperlukan bagi kebermamfaatan dirinya, masyarakatnya, dan lingkungannya, dalam kerangka meraih kesuksesan hidup didunia dan akhirat. berdasarkan alqur,an dan al Sunnah

B. pengembangan fitrah manusia melalui pendidikan adalah sebuah keniscayaan dalam rangka membimbing manusia untuk mengaktualisasikan potensi-potensi yang dimilikinya baik potensi penghambaan maupun potensi kekhalifahannya. Pendidikan menjadi kebutuhan mutlak manusia dalam kapasitasnya sebagai hamba karena sesungguhnya hungan manusia dan pendidikan itu sendiri adalah ibadah. dan dalam kapasitasnya sebagai khalifah pendidikan menjadi syarat utama dalam meraih potensi dan kelebihan-kelebihannya dibanding makhluk lainnya.

\section{SARAN}

Dalam melaksanakan proses kegiatan belajar mengajar di lembaga pendidikan Islam hendaknya para pendidik senantiasa untuk lebih memahami bagaimana hakikat dan urgensi pendidikan Islam karena tanpa mendalami dan memahaminya maka proses pendidikan khususnya dalam pendidikan Islam akan hanya bernilai sebuah kegiatan pemebelajaran yang lebih menitik beratkan pada peningkatan intelektual belaka karena fokus pada penguasaan materi pembelajaran tanpa mengarahkan hakikat, urgensi dan tujuan inti dari pembelajaran tersebut sehingga potensi-potensi yang dimiliki peserta didik tidak berkembang maksimal sebagaimana yang diharapkan oleh tujuan akhir dari pendidikan Islam.

\section{DAFTAR PUSTAKA}


Abudin Nata,Ilmu Pendidikan Islam,Jakarta: Kencana Prenada Media Grup,2010

Achmadi, Ideologi Pendidikan Islam;Paradigma Humanisme Teosentris, Yogyakarta: Pustaka Pelajar,2005

Ahmad Ali Riadi, Filsafat Pendidikan Islam, Cet.I;Yogyakarta:Teras,2010

Arif Rohman, Memahami Pendidikan dan Ilmu Pendidikan, Yogyakarta:Aswaja Pressindo, 2011.

Arif Rohman, Memahami Pendidikan dan Ilmu Pendidikan, Yogyakarta:Aswaja Pressindo, 2011)

Ghafar A. M.\& Mu'thi A. terj.Tafsir Ibnu Kastir jilid 5, Bogor: Pustaka Imam asy-Syafi'i, 2003

Hery Noer Aly, Ilmu Pendidikan Islam, Jakarta: Logos, 1999

Ismail Thaib, Wacana Baru Pendidikan, Yogyakarta:Genta Press,2008

Jalaluddin, Filsafat Pendidikan Islam; Telaah Sejarah dan pemikirannya, Jakarta:Kalam Mulia, 2011

Lexy J.Moleong, Metodlogi Penelitian Kualitatif, Bandung: Remaja Rosda Karya, 2013.

Martinis Yamin \& maisah, Orientasi Baru Ilmu Pendidikan, Jakarta: Referensi, 2012

Muhaimin. dkk. Paradigma Pendidikan Islam; Upaya mengefektifkan pendidikan agama Islam disekolah, Bandung; PT Remaja Rosda Karya, 2002

Muhammad Ereska, Pensucian Jiwa.(Jakarta: Iqra Kurnia Gemilang, 2005.

Ramayulis, Ilmu penddikan Islam, Jakarta : kalam Mulia, 2008

Samsul Nizar, Filsafat Pendidikan Islam;pendekatan Historis,Teoritis dan Praktis, Jakarta: Ciputat Pers, 2002

Sugiyono, Metode Penelitian Pendidikan; Pendekatan Kuantitatif, Kualitatif, dan RED, Bandung: Alvabeta, 2014.

Suharsimi Arikunto, Prosedur Penelitian Suatu Praktek, Jakarta: Reneka Cipta, 2006.

Teguh Wangsa Gandhi HW., Filsafat Pendidikan; Madzhab-madzhab Filsafat Pendidikan, Yogyakarta:ar-russ Media, 2011.

Zuhairini, Abdul Ghofir, Metodologi Pembelajaran Pendidikan Agama Islam Malang: UIN dan UM Press, 2004. 